\title{
Is Dhul Qarnayn, Alexander the Great? Reflecting on Muhammad Rāghib al-Ṭabbākh's contribution on a translated manuscript discovered in Timbuktu on Dul Qarnayn
}

\begin{tabular}{|c|c|}
\hline \multicolumn{2}{|c|}{$\begin{array}{l}\text { Authors: } \\
\text { Maniraj Sukdaven }{ }^{1} \\
\text { Shoayb Ahmed }\end{array}$} \\
\hline \multicolumn{2}{|c|}{$\begin{array}{l}\text { Affiliations: } \\
{ }^{1} \text { Department of Science of } \\
\text { Religion and Missiology, } \\
\text { University of Pretoria, } \\
\text { South Africa }\end{array}$} \\
\hline \multicolumn{2}{|c|}{$\begin{array}{l}\text { Corresponding author: } \\
\text { Maniraj Sukdaven, } \\
\text { sukdavenm@gmail.com }\end{array}$} \\
\hline \multicolumn{2}{|c|}{$\begin{array}{l}\text { Dates: } \\
\text { Received: } 01 \text { Sept. } 2016 \\
\text { Accepted: } 27 \text { Mar. } 2017 \\
\text { Published: } 26 \text { May } 2017\end{array}$} \\
\hline \multicolumn{2}{|c|}{$\begin{array}{l}\text { How to cite this article: } \\
\text { Sukdaven, M. \& Ahmed, S., } \\
\text { 2017, 'Is Dhul Qarnayn, } \\
\text { Alexander the Great? } \\
\text { Reflecting on Muhammad } \\
\text { Rāghib al-Tabbākh's } \\
\text { contribution on a translated } \\
\text { manuscript discovered in } \\
\text { Timbuktu on Dul Qarnayn', } \\
\text { Verbum et Ecclesia 38(1), } \\
\text { a1696. https://doi. } \\
\text { org/10.4102/ve.v38i1.1696 }\end{array}$} \\
\hline \multicolumn{2}{|c|}{$\begin{array}{l}\text { Copyright: } \\
\text { ( ) 2017. The Authors. } \\
\text { Licensee: AOSIS. This } \\
\text { is licensed under the } \\
\text { Creative Commons } \\
\text { Attribution License. }\end{array}$} \\
\hline \multicolumn{2}{|l|}{ Read online: } \\
\hline 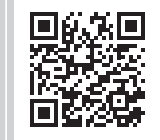 & $\begin{array}{l}\text { Scan this QR } \\
\text { code with your } \\
\text { smart phone or } \\
\text { mobile device } \\
\text { to read online. }\end{array}$ \\
\hline
\end{tabular}

This article emanates from a manuscript found in Timbuktu and digitised. The digitised version was subsequently translated by a team of translators and published as a book: Qissat Dhul Qarnayn [Tale of the two-horned one]. The most important question raised in reading this manuscript was the identity of Dhul Qarnayn. Subsequently to this manuscript being published as a book, a book written by Muḥammad Rāghib al-Ṭabbākh in 1949 in Arabic was examined, and it detailed a comprehensive scholarly study of the different views among scholars at that time about Dhul Qarnayn and Alexander the Great. This article reflects on the views of Muhammad Rāghib al-Ṭabbākh in his book together with the manuscript found in Timbuktu and brings together views that attempt to establish and understand who Dhul Qarnayn is or was and his adventures.

Intradisciplinary and/or interdisciplinary implications: The article elaborates on a topic that has been discussed by historians and theologians of the Jewish, Christian and Islamic faiths. It forms part of the discussion on apocalyptic literature. Within the Islamic context, it is often discussed among scholars dealing with the exegesis of the Qur'an and the Hadith. Some Sufi scholars tend to discuss it as well. It has intrigued some archaeologists. It highlights some civilisational issues at the time.

\section{Introduction}

A wealth of African scholarship is hidden in ancient manuscripts. Perhaps the most famous of these manuscripts are the Timbuktu manuscripts. They reflect a knowledge society that was engaged in the pursuit and application of knowledge. The Timbuktu manuscripts are a symbolic representation of the impact and influence of the early schools and universities (12th-16th centuries) that existed in West Africa. There were, however, other such knowledge societies in Africa where Africans engaged in reading and writing many centuries ago. These African manuscripts cover a variety of fields including astronomy, astrology, economics, mathematics, religion, culture and ethics. Most of these are written in Arabic, and the local 'Ajami' words that found its way into the texts, the historic language of scholarship in Africa (Diagne 2008:26).

In October 2015, a translation into English of one of these manuscripts, Qissat Dhul Qarnayn' (The story of the 'Two-horned King' known as Alexander the Great), was published (Sukdaven, Mukhtar \& Fernana 2015), which focussed on one of many Alexander the Great romances. The manuscript was written in $1736 \mathrm{CE}$ and is based on information from the Qur'an and other medieval Islamic sources that include the Hadith compilations. The author is unknown, and the only possibility is the mention of an individual by the name of Abu Abdel Malek. This work dealt with the topic of Dhul Qarnayn, as mentioned in the Qur'an in Surah Kahf, verses: 83-97. The topic of Dhul Qarnayn, the fort and the Ya'jūj and Ma'jüj (Gog and Magog) has intrigued many people. In fact, he was even known by the Jews because they were the ones who posed the question about Dhul Qarnayn to the Prophet Muhammad. ${ }^{1}$ However, ever since they have been mentioned in the Qur'an, there have been numerous scholars who have researched the topic eager to discover who this person was and when he lived.

1.Tafsîr ibn Kathïr, 5/136 
Sukdaven et al. (2015) quotes the narrator, Abu Abdel Malek, in his introduction to the manuscript as follows:

Historians differ in the tale of Dhul Qarnain. Some say he was a great king, sent to the people of Yemen, others say he was from Rome (Europe). Some say he was a prophet, others maintain he was just a messenger without any prophecy from God, because the Arch-Angel Gabriel was not revealed to him between Makah and Jerusalem ... It was also said that he is Tuba the great king of Yemen, while others say he was a saint loved by God. (p. 3)

The Timbuktu manuscript is based on the Alexander Romance and the Qur'an does not portray how Dhul Qarnayn's life ended. In fact, it ends rather abruptly with the exchange between Dhul Qarnayn and the Queen of Candace. It does not follow a chronological order, and it also mentions some of the Alexander's adventures that some contemporary historians including Tabbakh have not mentioned. Many of these adventures and travels are not substantiated with proof or references. Even some of the references made to traditions of the Prophet Muhammad are not supported with the names of the sources. This is one of the areas that distinguish Tabbakh because as a historian and a Hadith scholar, he provides references and some discussion on the strength of the narration. There are no time lines in terms of dates so following events is somewhat difficult.

The narrator seems to be inclined to two possible explanations with regard to the personality of Dhul Qarnayn; a king from Yemen and the other being the builder of Alexandria.

The above manuscript already highlighted the issues and difficulties of identifying exactly who Dhul Qarnayn was. Some documented their research in books dedicated to this topic. These scholars were diverse in their areas of specialisation. Traditional Hadith and history scholars, as well as a number of Sufi scholars, wrote about this topic. Classical scholars like Al-Ṭabarī (d. 923) (1986) and Al-Suyūṭi (d. 1505) (2003) are some examples of scholars who addressed this topic in their commentaries on the Qur'an.

From among these scholars, a renowned Syrian by the name of Muhammad Rāghib al-Ṭabbākh (hereafter referred to as Rāghib) (d. 1951) reflected on this personality. He wrote a book in Arabic titled Dhul Qarnayn wa Sadd al-Șin wherein he discussed in detail the arguments surrounding Dhul Qarnayn. This book was first published in 1949 and then again in the year 2003. The 2003 edition was edited by Abū 'Ubaydah Mashūr ibn Ḥasan Āl-Salmān and has some additional information contained in the footnotes. This article will attempt to provide a brief profile of the author and thereafter critically examine, with specific reference to the 2003 edition, the main ideas and theories that he presented with regard to Dhul Qarnayn and the aspects related to him. Rāghib's book on the topic is significant because he combined his expertise as a historian and his vast knowledge of Hadith. He used the methodology of the Hadith scholars to scrutinise and analyse the various reports and narrations, which included a study of the narrators and their credibility and reliability in transmitting such information. Because his writings are considered somewhat recent, this book is comprehensive in formulating the arguments centred on Dhul Qarnayn.

This article therefore reflects on the views of Muhammad Rāghib al-Ṭabbākh in his book together with the manuscript found in Timbuktu and brings together views that attempt to establish and understand who Dhul Qarnayn is or was and his adventures.

\section{Author's profile}

It is of tremendous importance that an understanding and the scholarly contributions of Rāghib are understood so as to lend credence to the value attached to this work on Dhul Qarnayn.

Yahyā al-Ṭabbākh, who is the son of the author and a specialist in history and the author of a book on his father, stated that his father Muhammad Rāghib al-Ṭabbākh was born in 1877 (1293 A.H). ${ }^{2}$

Rāghib was raised in a family of great scholarship, business and tasawwuf (the science dealing with self-reformation and discarding all bad characteristics and adopting pure and noble qualities). He began studying from the age of eight and commenced by learning the basics with regard to reading and writing and the recitation of the Qur'an. He also learnt Turkish, Persian and French. During his student years, he memorised many didactic poems dealing with various Islamic Sciences. When he was 14 years old, he visited the cities of Makkah and Madinah where he met and engaged with many scholars and observed some of their gatherings and listened to their discussions.

Over the years, he met illustrious scholars in Syria and elsewhere, and those who he was unable to meet, he corresponded with through letters. He also interacted and corresponded with a few orientalist scholars like David Margoliouth (d. 1940). These orientalists gained tremendously from his extensive knowledge, especially his expertise with regard to Arabic manuscripts.

Despite being an avid reader and researcher, he found time to engage in journalism, teaching and guiding the public. His articles in various magazines and newspapers were well received by the public and scholars alike. ${ }^{3}$ He taught at the prestigious Khesrevye School in Aleppo and even took it upon himself to improve and amend the syllabus so that it met the requirements of the time. He introduced subjects like mathematics, geography and natural science. Eventually in 1937, he was appointed as the director of the religious academic school.

He was passionate about the city of Aleppo and its history including its architectural legacy. This is apparent in his

2.From the introduction by the author's son and the short biography by $S$. Ah med (2006), p. 185.

3. His articles were collected and compiled in a two volume book titled Maqālāt alAllaāmah Muhammad Rāghib al-Tabbākh by Shaykh Majd Makkī (2015). This book was published in 2015 . 
book, Ilām al-Nubalā (1988). He authored numerous other books that covered a range of topics from history, biographies of his teachers along with the respective chains of transmission and even compilations of classical Arabic poetry. This is an indication of his versatility as a scholar. He served in many academic organisations, and his last role was as president of the League of Ulama for the city of Aleppo. He served in this position until his death in 1951 (29 Ramadan 1370).

Two scholars that are known to have had a tremendous impact on him were Muhammad Zarqā (d. 1924), who was an erudite scholar and specialist in Islamic Jurisprudence (Fiqh) of the Hanafi madhhab (school of thought) and Bashīr alGhazzī (d. 1920), who was a member of the court in charge of fatwa and a specialist in the Arabic language and its poetry.

His son, Yahya, has listed at least 14 published and about 13 unpublished works by his father. One such published work is the book that we are reviewing and which is a rather detailed work on Dhul Qarnayn and the Wall.

\section{Theories, views and arguments on Dhul Qarnayn}

With the establishment of Rāghib as an astute scholar, we now turn to his book and will focus on Rāghib's examination of the theories, views and arguments on Dhul Qarnayn by a plethora of scholars. We do this by addressing the following fundamental questions:

- Who are the people who posed the question regarding Dhul Qarnayn?

- Who is Dhul Qarnayn?

- Why was he called Dhul Qarnayn?

- What was the extent of Dhul Qarnayn's control on earth?

- Why was Dhul Qarnayn granted such power and control?

- Why did Dhul Qarnayn follow the cause that he did?

We will try and summarise a response by Rāghib in his book to each of these questions.

\section{Who are the people who posed the question regarding Dhul Qarnayn?}

In answering the first question, he is certain that the questioners were some Jews who included this among a list of other questions that they posed to the Prophet Muhammad (Al-Ṭabbākh 2003:37). There seemed to be consensus among scholars regarding the answer to this question. It is therefore not necessary to pursue this question any further as there were no real contrary arguments to this fact.

\section{Who is Dhul Qarnayn?}

However, when discussing the second question, Rāghib cites various opinions and then discusses them rather critically. Because of his expertise as a historian and a scholar of Hadith, the methodology adopted by these two categories of scholars is apparent in his writing and is further enhanced by the work of the editor of the 2003 edition, Abu 'Ubaydah Mashūr ibn Ḥasan Āl-Salmān. The Hadīth scholars confirmed the authenticity of a narration by carefully scrutinising the background, memory, credibility and reliability of the narrator.

\section{Statement 1: Dhul Qarnayn is Alexander the Great}

One of the opinions Rāghib cites in this regard is that Dhul Qarnayn was Alexander the Great (also referred to as the Greek or Macedonian). According to Rāghib, this view was proposed by some scholars because Alexander's kingdom extended over the east and the west. Ibn Sīnā (d. 1037) (Avicenna) in his book, al-Shifā (1952) and others describe him as one of the greatest kings. He was powerful and a follower of Aristotle. This view is held by a number of classical and traditional Muslim scholars like al-Rāzī (d. 1209), Abū Ḥayyān, (d. 1344) (1993:150) and Abū al-Sa'ūd, (d. 1574) (1936:557) among others. Rāghib mentions that Ālūsī, (d. 1854) (2008:24), a famous Iraqi commentator of the Qur'an, seemed somewhat convinced of this view.

Abū al-Fidā (d. 1331) also looks at the possibility of Dhul Qarnayn being Alexander. In his book al-Mukhtașar fì Akhbār al-Bashar, Abū al-Fidā (2010:79) mentions that numerous stories have been circulated in this regard and are similar to the additional information many storytellers quote with reference to many prophets. These results are a culmination of pieces of information that very often are not authentic because they have never been verified or authenticated.

Upon investigating, Jāḥiz (d. 868) (1965), who was a renowned scholar, seemed somewhat convinced that Dhul Qarnayn was Alexander, the destroyer of Dārā (Darius). Rāghib considered this view to be incorrect as he was convinced that he was in fact an Arab. Furthermore, the credibility of Jāhiz as a narrator is somewhat questionable by the scholars and specialists of Hadith. Ibn Hazm (d. 1064) (1929:195) and Al-Dhahabī (d. 1348) (2000:247) regarded him as a person who was not careful and particular when he transmitted narrations and was somewhat impudent. ${ }^{4}$

\section{Statement 2: Alexander the Great was a prophet}

Another view highlighted by Rāghib was that some Muslim storytellers tried to elevate the status of Alexander to that of a prophet in the category of the Prophet Sulaymān who combined wisdom, knowledge and a huge kingdom together. However, some specialists on Greek Civilisation and history like Abū Sulaymān al-Sijistānī (d. 1000) who was of Greek origins and very well acquainted with philosophy and rational sciences stated that there was no prophet from among the Greeks. ${ }^{5}$ So in all probability, these Greek stories reached the Muslims via the Persians. It is not strange then that the translation of some letters between Aristotle and Alexander is attributed to Sālim, the freed slave of Hishām ibn `Abd al-Malik (d. 743) (Ibn Nadīm 1997:177).

4.Mizan al-Itidal, 3/247 and al-Fisl fi al-Millal 4/195.

5.Abū Hayyān Al-Tawhīīi, 2/22. 


\section{Statement 3: Alexander the Great as brother of Dara}

A somewhat stranger position, mentioned by Rāghib, is when some tried to depict Alexander as the brother of Dārā ibn Dārā through some marriage between a Persian and a Roman. It is worthy to note that even a master in history like Imām al-Ṭabarī (d. 923) in his book (Ṭabarī 1990:576) quotes from some Persian sources with regard to Dhul Qarnayn while also discussing Dārā and his son. In these discussions, Tâbari was somewhat inclined to view Alexander as the brother of Dārā. It must be mentioned that some Greek sources cited by Rāghib have provided extra information on how Alexander killed Dārā. These sources also mention that Alexander did not ascribe to any religion. If this is true, then how could he be the person mentioned in the Qur'an?

\section{Statement 4: Alexander the Great as Dhul Qarnayn}

Rāghib suggests that other scholars refute the notion that Dhul Qarnayn is Alexander by stating that the word 'Dhul Qarnayn' is a title used to refer to certain kings of Yemen such as Dhul-Nawās. In addition, Alexander was Greek and a unbeliever. They maintain that because Allah praised him in the Qur'an, he would at least have had been a believer. Alexander, on the other hand, was a polytheist. Al-Sharastāni (d. 1153) in his book al-Millal wa al-Nihal (1992:117) also distances the possibility of him being Alexander. Al-Rāzī (1981:141) elsewhere in his commentary asserts that Dhul Qarnayn was a prophet while Alexander was a unbeliever who was educated by Aristotle. Rāghib took notice that some scholars of Qur'anic exegesis have quoted a narration wherein mention is made of a number of questions that the Jews posed to the Prophet Muhammad to try and disprove his prophet-hood. After examination, it appears that most of these reports are not authentic and cannot be relied upon. The scholars of Hadith like Abū Dāwūd (d. 889) have quoted a narration wherein the Prophet Muhammad said: 'I don't know if Dhul Qarnayn was a prophet or not' ('Aẓ̄im 'Abādī 1995:336).

According to Rāghib, a substantial number of scholars have supported the view that Dhul Qarnayn was not a prophet but rather a pious and just man.

Many historians who have written about Egypt in general and specifically about the city Alexandria have discussed Alexander, and they are almost unanimous in classifying him among the wise men of the time and not among the prophets. This is supported by a report from Ibn 'Asākir (d. 1175) in his monumental book Tārikh Dimashq (Ibn 'Asākir 1995b:336), which states that the earth was ruled by four people. Two were believers and two were unbelievers. The believers were Sulaymān and Dhul Qarnayn, and the unbelievers were Namrūd and Bukht Nassar.

Another Syrian scholar, Jamāl al-Dīn al-Qāsimī (d. 1914) (AlQāsimī 1957:4103) in his commentary on the Qur'an cited Ibn Taymiyyah (d. 1328) and his student Ibn al-Qayyim (d. 1350) among the scholars who distinguished between Dhul Qarnayn and Alexander. A contemporary Egyptian scholar and historian, Rajab al-Bayyūmī (d. 2011) in his writing on the Qur'an also examined the personality of Alexander and proved that he was an oppressive person who did not fit the description of the personality of Dhul Qarnayn mentioned in the Qur'an. He maintains that the former is reported to have butchered many people including children.

Abū al-Yusr 'Ābidīn (d. 1981), a Syrian scholar and Mufti, confirmed in his book Aghlāt al-Mu'arrikhīn (1957:287-300) that Dhul Qarnayn was an Arab Muslim from Himyar in Yemen. He supported his view by taking into consideration his age and the age of Alexander among various other factors. Abū al-Rayhān al-Birūni (d. 1048) in his book al-Āthār alBāqiyah 'an al-Qur'an al-Khāliyah (2007:36) also held this view.

There are scholars, as noted by Rāghib, who, in supporting the second view, state that Dhul Qarnayn was a contemporary of Prophet Ibrāhīm and that Alexander was a totally different person. The latter lived 300 years before the Prophet 'Isā. He was a student of Aristotle and corresponded with him on whether or not he ought to fight and wage war against the Persians. Alexander's lifespan was short and his reign was even shorter.

So in concluding this discussion, Rāghib refers to those who are certain that Dhul Qarnayn was an Arab and they have based their view on the following:

- The prefix Dhu is used for certain Arab tribes.

- He met with Prophet Ibrāhīm. This is more likely with an Arab.

- Some reports claim that al-Khidr was related to him. This too is more likely with an Arab than a non-Arab.

- His amazing victories are a clear indication of some divine assistance. This was supported by renowned classical Qur'anic exegists like Ibn Kathīr and Kātib Halabī.

- The lifespan mentioned by the historians is more suited to the Prophet Ibrāhīm's era than Prophet 'Isā because during the latter the lifespan decreased substantially.

Other scholars, such as al-Rāzī, were of the opinion that Dhul Qarnayn was an Arab known as Abu Karb Shams ibn Abīr al-Himyarī. He is said to have been a powerful king with a huge kingdom.

\section{Statement 5: Dhul Qarnayn was an Arab}

Rāghib notes that Ibn Sa'īd al-Maghribī (d. 1286) who was a poet and a historian (Al-Maghribī 1982:112-115) quotes a narration from the companion of the Prophet Muhammad, Ibn 'Abbās who said that Dhul Qarnayn was from Himyar. This is supposedly based on a narration from Ibn 'Asākir and others with a weak chain of transmission. He mentions another view, which suggests that Dhul Qarnayn was an Arab but his name was al-Șa'b ibn Rā'ish. A narration from Ka'b maintains that Dhul Qarnayn was Șa'b ibn Murā'id, while Alexander was from the children of Greece. Rāghib continues by stating that others have claimed that Dhul Qarnayn's name was Afridūn ibn al-Daḥ̣̄̄k. Al-'Aynī who 
was another renowned commentator to the famous Hadith corpus, Șaḥịh al-Bukhārī (Al-Bukhārī 2002:114) also confirmed that Dhul Qarnayn was indeed an Arab but his name was 'Abd Allah ibn al-Daḥhāk (2005:233). He did allude to the name Șa'b.

It is interesting to note that the name Dhul Qarnayn features in many Arab poems particularly classical Arab poetry including the pre-Islamic poetry. He is mentioned in the poetry of Imru al-Qays, Aws ibn Hajr and Tarfah ibn 'Abd (Al-Zawzanī 1983:23).

The reason for the narration regarding his 'Arab' lineage is because among the Arabs if a man died leaving behind a young son, then the widow married someone else from another tribe; her son from the first husband will grow up in the home of the second husband. So those who knew him attribute him to his biological father, while those who did not attributed him to the man in whose home he was raised.

Rāghib provides numerous additional proofs indicating that Dhul Qarnayn was indeed an Arab. By mentioning Dhul Qarnayn before Prophet Ibrāhīm, there is a subtle indication and refutation of the possibility of him being Alexander the Greek. As had been mentioned earlier, Alexander was closer to the period of Prophet 'Isā (Jesus). There was a difference of at least 1000 years between Prophet Ibrāhīm and Prophet 'Isā. It seems the latter Dhul Qarnayn, the one during the time of Prophet 'Isa, was given the same title because of the similarity with the first, the one who lived in Prophet Ibrāhīm's time.

Rāghib quotes al-Fākihī (d. 893) in Akhbār Makkah (Al-Fākihī 1994:393-394) who cites a narration that Dhul Qarnayn performed the pilgrimage to Makkah on foot and it was then that he met Prophet Ibrāhīm. Rāghib discusses various reports including those who indicated that he lived a long life. This is discussed by historians and commentators on the Qur'an such as Ibn Kathīr (1999:136) who acknowledged that this could have been possible because in that era people did live long. This is supported by the Qur'an when reference was made to Prophet Nūḥ (Noah) in Sūrah al-'Ankabūt, verse: 14 'We sent Nūh to his people and he remained among them for 50 short of a 1000 years who remained among his people for 950 years'. ${ }^{6}$

Other historians are inclined to believe that Dhul Qarnayn lived in the time of Prophet Sulaymān and met Bilqīs, the Queen of Sheba. In an article published in a magazine in 1955, the writer was certain that the Wall behind which Ya'jüj and Ma'jūj were imprisoned is indeed the Great Wall of China (Al-`Irfān article by Muhammad Jamīl Baylam, no. 32, 1962). He mentioned that he was even more certain after he visited the Wall.

The Chapter on the Cave (Surah: 18) in the Qur'an that discusses Dhul Qarnayn also discusses the encounter between Prophet Mūsā and a wise man known as Khiḍr.

6.English translations of all verses from the Qur'an are based on the translation by Aisha Bewley (1999).
During this meeting, various questions were posed by Mūsā to Khiḍr from which many lessons were learnt. Many Muslim scholars then looked into the details with regard to Khiḍr's personality and whether or not he was a prophet? They also researched the possibility of him still being alive and the possible meeting with him and various prominent personalities throughout history including Prophet Ilyās (Elijah) (Al-Suyūṭī 2003:580).

Rāghib discusses the supposed meeting between Dhul Qarnayn and Khider. ${ }^{7}$ This, however, is not established. There is a lengthy narration that mentions the attempt by Dhul Qarnayn and Khiḍr to locate the 'spring of life'. Hāfiz Ibn 'Asākir (Ibn 'Asākir 1995a:419) disregards this narration because of the clear signs in it that indicate that it is very weak and thus not reliable. This alleged meeting has been refuted by more than one scholar as well as the even stranger encounter with the bird that posed some questions to him. The classical Ḥadīth scholar, Ibn Ḥajr al-'Asqalānī (d. 1449) (Al-'Asqalānī 1995:290) looked at where Dhul Qarnayn was mentioned in the Qur'an and indicated that he is mentioned in close proximity to the incident of the Prophet Mūsā (Moses) and his encounter with Khiḍr. Furthermore, Prophet Mūsā lived a long time prior to Prophet 'Isā. The meeting with Khiḍr gives way to another debate among Muslim scholars, which deals with whether or not Khidr is still alive? Many renowned classical Muslim scholars have rejected the possibility of him being alive.

\section{Statement 6: Dhul Qarnayn was an angel}

The other view mentioned by Rāghib was that Dhul Qarnayn was an angel. Even though this view was maintained by a few scholars, it is far from correct. One such scholar was Rāghib Bāshā (d. 1176). This view seems to have some Babylonian influence and has somewhat influenced some Muslim scholars especially those who claimed that Alexander was a result of a marriage between a human being and an angel. There is mention of yet another view that regards the word 'Dhul Qarnayn' as one of the names of the angels. This is attributed to Ibn 'Abd al-Hakam (d. 871) in his book Futūh Miṣr (Ibn 'Abd al-Hakam 1981:187) but it has a somewhat weak chain of transmission. Many of these narrations do not meet the requirements and criteria that have been formulated by the scholars of Hadith, and therefore, they cannot be relied upon. There is yet another view that claims Dhul Qarnayn was a result from human and jinn because his mother was jinn. This view can be found in the book titled al-Hayawān by Al-Jāhiz (1965:245). This view seems to have been influenced by some Latin sources because it is in accordance with some European sources that are more concerned with folklore.

\section{Why was he called Dhul Qarnayn?}

Rāghib explored yet another view that is based upon a narration from al-Hasan recorded by Ibn 'Asākir in

7.Khidr is the man Prophet Müsä met. Various books have been written about him and his lifespan. One of these is an adaptation of Ibn Hajr's (d. 1448) work in his book al-Ișā
(d. 1919). 
Tārikh Dimashq (The History of Damascus) that mentions that he was known as Dhul Qarnayn because his hair was divided into two plaits.

Rāghib regards one of the best pieces of research on the topic to be the work by Qāội Abū al-Ḥasan 'Alī ibn 'Abd al-'Azīz al-Jurjānī (d. 1001) in his commentary on the Qur'an known as Tafsìr al-Qur'an al-Majīd, wherein he rejected all these other possibilities. Rāghib summarised his findings and conclusions as follows:

- One is not inclined to many of these narrations because they do not appear to be sound.

- The Qur'an did not provide detail on the topic.

- Later scholars researched and studied the topic and presented their views. But their conclusions contain many doubts and uncertainty.

So thus far, it seems like the details on the history of Dhul Qarnayn appear to be a combination of various historical evidences from Islamic and other sources and the imagination of the storytellers. This is similar to the translated manuscript, which was found in Timbuktu (Qissat Dhul Qarnayn' [The story of the 'Two-horned King' known as Alexander the Great $\{2015\}])$. One of the reasons for the varying views among Muslim scholars though is because the Qur'an does not provide much detail and the Greek and Persians prior to Islam also differed greatly on this topic.

A scholar known as Al-Maqrīzī (d. 1441) (1985:191) wrote in al-Mawa' $i z$ about the distinction between Dhul Qarnayn and Alexander and even provided a lineage to the Prophet Nūh. This lends some strength to the view that Dhul Qarnayn was in fact an Arab because the Arabs trace their lineage to Sām ibn Nūḥ.

Rāghib makes mention of an old classical historian known as Ibn Hishām (1990) who was of the view that Dhul Qarnayn was from Egypt and his name was Mirzibān ibn Mirdhabah and he was called Alexander because he built the city Alexandria. Regardless of its authenticity, it has been mentioned by Ibn Kathīr (d. 1375) (2010:219) in his lengthy history encyclopaedia titled al-Bidāyah wa al-Nihāyah. Scholars like al-Suhaylī (d. 1185) (Al-Suhaylī 2000:59) distanced themselves from this view. Rāghib also discusses the history of the city of Alexandria with specific focus on who built it. He cites Tärikh of Al-Ṭabarī who quoted a lengthy narration that somewhat confirmed that Alexander, the Macedonian, did indeed travel extensively but there is no mention of him having built the Wall or the city.

Yāqūt al-Ḥamawī (d. 1229) (Al-Ḥamawī 1993:197-200) who was a famous calligrapher and a historian also questioned and distanced himself from this possibility because travelling at that time was even more cumbersome, tedious and difficult, so how would a young man in his twenties be able to do so along with his army? How was he able to conquer a region in Asia reaching China? One needs to be mindful of the fact that in order to achieve this, there is a need for food and other supplies. In addition when and how did he get the chance to build a great Wall and rebuild all that was destroyed? Achieving this requires many years and it is not likely that a young man in his twenties possessed such lofty aspirations. Yes, some may assert that the Tartars inflicted great destruction in a short space of 2 years. But then, it is much easier to destroy than to rebuild. Some storytellers went to the extent of claiming that he built famous cities like Asbahan and Samarqand. These are all baseless claims according to al-Hamawi.

There are historians who maintain that Alexander the Greek never reached China. He engaged in battles in Persia and India and reached the outskirts of China.

\section{Why he was called Dhul Qarnayn or the 'The Possessor of Two Horns'?}

A number of possibilities have been presented by Rāghib. These are as follows:

- Khiḍr was the first to call him by this name and it was Khiḍr who referred to him as the person of the two horns of the sun.

- Al-Rāzī mentioned that he was called Dhul Qarnayn because it was during his time that two generations of people ended.

- Another view claims that the upper portion of his head was of copper.

- Another view states that he had on his head what resembled two horns.

- There is a view that his crown had two horns.

- Because he traversed the east and the west.

- His hair was divided into two plaits.

- Because of his bravery.

- Because of a dream he saw.

Rāghib seems to prefer the view that he was called Dhul Qarnayn because he travelled from the east to the west. This view, according to Rāghib, was supported by a number of senior classical scholars.

\section{How long did he remain on earth?}

This discussion emanates from verse: 84 of Sūrah al-Kahf (The Cave) in the Qur'an wherein Allah says: 'Indeed, We have established him on earth'. Before trying to attribute any time to Dhul Qarnayn's stay on earth, it must be noted that some scholars were of the view that the above verse is referring to prophet-hood, while others said it refers to kingdom. The commentator of the Qur'an, Al-Baydāāi (d. 1286) (1997:291), was of the view that the verse meant that he travelled the earth freely. In addition, he was granted everything that made his affairs easy and enabled him to fulfil his tasks with tremendous ease. Others have stated that the verse implies that he was granted great knowledge that allowed him to achieve his objectives much easier. Another view claims that he was granted control of the landmarks on earth. 'Abd al-Rahmmān ibn Zayd ibn Aslam (d. 798) was of the view that he was bestowed with the ability of knowing 
different languages. This meant that whenever he went into battle against any nation he addressed them in their own language.

Rāghib concluded that Dhul Qarnayn was granted everything that eased and facilitated matters for him in his kingdom. He used these means to help him attain his goals and objectives.

\section{What is known with regard to Dhul Qarnayn's journey to the Far West?}

The reason for this discussion is also based on the verses in the Qur'an. In this case, verses: 86-87 of Sūrah al-Kahf, 'Then he followed a way until he reached the rising of the sun and found it rising on a people to whom We had not given any shelter from it'.

Rāghib said that he was certain that Dhul Qarnayn, the one who built the Wall, is an Arab and he travelled extensively until he reached the furthermost region to the west. He travelled across Africa, then into Andalus (Spain) and then further west until he reached present day America. He quotes the author of the book al-Tijān (Ibn Munabbih 1928:446) who stated that Dhul Qarnayn sailed with his army until he reached some islands in the Atlantic Ocean. Some historians have established that these islands were the Canary Islands. It appears that the inhabitants did not understand him and he wanted to fight them but he was stopped from doing so by Khidrr. Thereafter, he continued sailing westwards until he eventually reached America. Thus, Rāghib maintains that Dhul Qarnayn was the first to discover America. It is interesting to note that some 8 years after writing this, Rāghib came across articles written by non-Muslims that were published in the years 1944 and 1948 in various Egyptian magazines like al-Muqtataf and al-Risalah, which confirmed that the Arabs were aware of America before the west and more specifically before Columbus. Later scholars established that some Arabs settled in the area known as Mexico. They based this on the presence of some words in the area that even the local people are unaware of its origins. The word 'alligator' is one such word. The Arabs were also aware of the islands to the west of Great Britain that were known by Greeks as Kasselerides. The reason for their success is attributed to the following:

- They were excellent sailors.

- They were excellent ship builders.

- They were masters in the field of engineering.

- They possessed very good and reliable information about the Gulf Stream, which are related to the great currents in the Atlantic.

In 2000 the late Moroccan professor, 'Alī al-Kettānī (d. 2002), delivered a lecture in Rabat wherein he proved without doubt that the Arabs had indeed arrived in America before Columbus. He verified this with renowned Spanish authorities on the topic (al-Kettānī 2009). In addition, Columbus, in his diary, testified to this. In fact, he even wrote about the religion of the inhabitants of the Caribbean and confirmed that they were monotheists (al-Kettānī 2009).

On the contrary, there are numerous non-Muslim historians who have confirmed that Muslim sailors reached as far as Iceland. Rāghib then provides some proofs that the Muslims were certainly aware of the geography of the time. This reinforces the notion that they had indeed travelled to these regions. Historians have confirmed that some Muslim scholars had drawn an accurate sketch of two continents. This was done long before western scholars had done so.

This discussion eventually leads him to another topic and that is in the shape of the earth. The reason for this is that there were some scholars in the past as well as some during the author's era that doubted in the oval nature of the earth. While discussing this, he also discusses the Arabs and their connection to the Mediterranean Sea. He substantiates with proofs from a number of prominent scholars like al-Mas' $\mathbf{u} \mathbf{i}$. These quotations among other are clear indications from these scholars on the oval shape of the earth. Much of these facts were discovered much later by other scholars.

He then discusses a certain island on which Hercules is supposed to have built some huge pillars. Some of the inhabitants lost their way and found themselves in a strange land where they were imprisoned for 3 days. On the 4th day, they were addressed by a person who spoke Arabic. Some have speculated that these sailors were in an area near to or possibly close to the Bermuda.

The author then quotes Ibn Fadl Allah al-'Umarī (d. 1384) who in his book titled Masālik al-Abșār fì Mamālik al-Amșār spoke about a King Mūsā ibn Abī Bakr from Mali who mentioned that he came into power when the king before him travelled with over 1000 ships on the ocean eager to find the end and he never returned. It is assumed by some scholars that Columbus was aware of these initial travellers and he probably read some of their diaries or writings. Columbus in his travels is supposed to have reached the land known as San Salvador.

Rāghib continued in his discussion and investigation on the travels of Dhul Qarnayn with some special attention on the explanation of the verse in the Qur'an that deals with the place of the setting of the sun. He quoted a number of classical commentators of the Qur'an like Imām al-Rāzī who in his exegesis actually confirmed many scientific facts including the fact that the sun is much larger than the earth. It appeared to Dhul Qarnayn that the sun was setting in the ocean or in a spring of water. Other scholars are of the view that he reached a land that no person could traverse.

Imām al-Nasafī (d. 1310) (Al-Nasafī 1998:318) in his commentary to the Qur'an said that some scholars looked at the context and used this to conclude that Dhul Qarnayn could have been a prophet. 
Al-Azraqi (d. 837) (2004:36), who is a famous historian of Makkah, along with a few other scholars maintained that Dhul Qarnayn accepted Islam at Prophet Ibrāhīm's hands and circumambulated the Ka'bah with him. This strengthens the view that he was a pious and righteous servant of Allah.

The author then discusses Dhul Qarnayn's return from the west and his journey to the east. He again mentions various opinions among these are those who said that he returned over a period of 12 years and reached the point from where the sun rises. He came across a nation that did not possess any homes and when the heat was very intense they sought refuge.

The context of these verses (i.e. 89-93) of Sūrah al-Kahf 'Then he followed a path until he arrived between the two mountains where he found a people scarcely able to understand speech ...' also indicates that during his travels he came across the area between two mountains and this was the region where Ya'jūj and Ma'jūj emerged from.

He cites the view of Al-Khatīb (d. 1570) (1881:404) who in his commentary to the Qur'an titled al-Sirāj al-Munìr spoke about various maps of China that appear in the book alNukhbah al-Azhariyyah fĩ al-Kurah al-Ardiyyah (1903:268) in which there are clear indications of this barrier or fort. He goes on to mention the Gobi Desert that is inhabited by the Moguls who according to him are Ya'jüj and Ma'jüj.

The author also speaks about the region between the Black Sea and the Khazar Sea where he spoke about an area that he referred to a 'natural wall'. This is somewhere in present day Turkistan.

Dhul Qarnayn and Khị̣r while on their journey passed an area known as al-Jazirah, which is north of Mosul and is probably presently in Mardin, Turkey.

\section{Who were Ya'jūj and Ma'jūj?}

Because any discussion on Dhul Qarnayn cannot be completed without mentioning Ya'jūj and Ma'jūj, Rāghib dedicates some time trying to understand who they really are and some of their characteristics.

He quotes a Hadith that is recorded in the two famous and authentic compilations by al-Bukhārī and Muslim (2006:120) wherein the Prophet Muhammad said that from every 1000 people, 999 will enter the fire of Hell. The Companions of the Prophet enquired about the one that will be saved. The reply from the Prophet comforted them when he said that the 999 are from Ya'jūj and Ma'jūj.

Ya'jūj and Ma'jūj are also from the progeny of Prophet Nūh and this is based upon a prophetic narration reported by Imām Al-Tirmidhī (1996:280) in his Hadīth compilation wherein the Prophet said that Nūḥ had three sons; Sām, Hāam, and Yâfith. Sām is the father of the Arabs, Hām is the father of the Africans and Yāfith is the father of the Turks.
Ya'jūj and Ma'jūj are a group from the Moguls who are from the progeny of the Turks.

Rāghib mentioned that there are numerous reports from Prophet Muhammad that confirm their existence and their large numbers to the extent that one of them will not die until he saw at least 1000 from his progeny. There are other narrations that provide some detail on how tall or short they were but these are baseless or very weak according to Rāghib.

The above is the common view but it is interesting to note that there were a few other opinions. One stated that Ya'jujj and Ma'jūj were in Yemen because a large Wall was discovered in the 10th century. Another view maintains that they were in Derband in Russia. The editor, Abu 'Ubaydah Mashūr ibn Hasan, elaborated and stated that the latter view was held by two prominent Indian scholars with slight variations in the detail. These scholars were Shiblī Nomānī (d. 1914) and Abū al-Kalām Azād (d. 1958) in their Urdu rendition of the meanings of the Qur'an. They were somewhat certain that the Wall is in the Caucasus region of Russia. The latter seemed more convinced of his view after he visited Iran and surrounding areas; and he claimed to have seen the Wall.

\section{The building and significance of the Wall}

The author then discussed the building of the Wall and goes into details with regard to the story as mentioned in the Qur'an. This involves the plea of the local people to Dhul Qarnayn to do something to protect them from Ya'jüj and Ma'jüj. He discussed the material used to build the Wall and provides some description of the Wall. He then mentions a book written by Abū Dalf Mis'ar ibn Muhallil who described his travels to China. The author of this book mentioned Qulayb an area in China where there were Arabs who remained there after Tubba', a king of Yemen had waged war against the Chinese. There are some reports that Yemeni kings ruled over parts of that region for about 320 years.

Rāghib then confirms that the Arabs had rediscovered this area during the time of the 2nd Caliph, 'Umar. It was 'Abd al-Rahmān ibn Rabī'ah who was one of 'Umar's generals and along with his army had reached this land in around $19 \mathrm{AH}$. This was followed by the 'Abbasid leader, al-Wāthiq Hārūn, who ascended the throne in the year 227 and died in $232 \mathrm{AH}$ and his dream. After the dream he commissioned a group who travelled for a long period until they eventually reached the Wall where they found people who were Muslim and who spoke Arabic. Thereafter the author commented saying that he wrote based on the historical narrations and he does not attest to its authenticity. However he does acknowledge its existence because it is mentioned in the Qur'an.

Mention is made of Ya'jüj and Ma'jūj and their attempts to make a hole in the Wall through which they could escape but they failed. The author believed that the opening and various other aspects will not take place simultaneously, instead these will occur gradually and the evil and corruption will 
also take place more than once, but their greater emergence that will have serious consequences will take place closer to the Day of Judgement.

The author also quotes some western scholars such as Hadland Davis from other faiths who acknowledged the existence of the Wall. Some maintained that it was built about 214 years before the birth of Prophet 'Isā. Many of these scholars provided detail with regard to the length of the Wall and the type of brick and other material used to build it. They also speak about the different Chinese emperors and their dedication in repairing the Wall. Because of the uncertainty around their exact location, the extra details about the materials used to build it are not significant and cannot be relied upon.

The Qur'an the Hadith make mention of an opening in the Wall. In fact, the Prophet Muhammad spoke about destruction that will befall the Arabs because of some evil that is close and eminent. This was when a small hole opened up in the Wall.

Assuming as some scholars believed that the Moguls are actually the Ya'jūj and Ma'jūj, then they were eventually successful in breaking out of this prison. This was in the latter part of the 6th century and the early 7th century. They, under their leader Genghis Khan, caused havoc by killing thousands of people and this continued under Holaku and again in around 1399 under Timurlane as stated by Kohn (1999:485).

Despite the havoc and bloodshed during the times mentioned above, they will reappear prior to the Day of Judgement because Prophet Muhammad included them among the 10 major signs prior to the Day. So how do we reconcile with the reports that confirm a small opening? This could be that the hole was far too small for them to emerge. If indeed it was them who caused all the destruction, then it is not impossible for them to reappear with even more drastic consequences. At some point, Shaykh Rāghib thought that the Japanese could be included among Ya'jūj and Ma'jüj. However, in 1949 some 9 years after completing this book and after the Second World War and the destruction of Japan, he reconsidered his position.

\section{Conclusion}

This book written by Rāghib has provided a very comprehensive yet detailed examination of the controversies and debates surrounding Dhul Qarnayn and Alexander the Great. This discussion can be concluded by confirming that since the Qur'an and the Hadīth have both mentioned Ya'jūj and Ma'jüj, Dhul Qarnayn and the Wall, these were indeed real events even though some contemporary scholars and explorers have denied it because of their failure to locate it.

Is it possible for scientists and researchers who have dated certain fossils back some 50000 years, to use some similar modern technology to conclusively locate the whereabouts of Ya'jūj and Ma'jūj and the Wall? After all the mention of Ya'jūj and Ma'jūj and the Wall are to be found also in the Jewish and Christian literature.

Finally, the manuscript discovered and digitised from Timbuktu on Alexander the Great and Dhul Qarnayn, may have been influenced by many stories in existence and brought to bear and thus created the debate as to who is Dhul Qarnayn exactly. This discussion was comprehensively examined, and it is the conclusion of the authors of this article that Alexander the Great and Dhul Qarnayn are two different individuals; hence, the limited mention of Dhul Qarnayn in the Qur'an.

\section{Acknowledgements Competing interests}

The authors declare that they have no financial or personal relationships that may have inappropriately influenced them in writing this article.

\section{Authors' contributions}

M.S. as the project leader was responsible for the systematic formulation and argumentation expressed in the article. S.A. is the PhD student of M.S. and serves as the Research Assistant to M.S. S.A. was responsible for the translation of the text and together with M.S. was responsible in subjecting the Timbuktu manuscript to the views of Muhammad Rāghib al-Ṭabbākh.

\section{References $^{8,9}$}

Ābidīn, Abū al-Yusr, 1957, Aghlāṭ al-Mu'arrikihīn, Damascus.

Abū al-Fidā, 'Imād al-Dīn Ismāīil ibn 'Alī, 2010, al-Mukhtașar fi Akhbār al-Bashr (vol. 1), al-Mațba'ah al-Ḥusayniyah al-Mișriyyah, Egypt.

Abū Ḥayyān, Muhammad ibn Yūsuf, 1993, al-Baḥr al-Muhịị (vol. 6), Dār al-Kutub al-'llmiyyah, Beirut.

Ahmed, S., 2006, Muslim scholars of the 20th century, Kawthar Publications, Pretoria.

Al-'Asqalānī, Ibn Hajr, 1995, al-Ișābah fi Tamyīz al-Ṣahāābah (vol. 2), Dār al-Kutub al-'llmiyyah, Beirut.

Al-'Aynī, Maḥmūd ibn Ahmmad, 2005, 'Umdat al-Qārī (vol. 15), Idārat al-Ṭibā'at al-Munīiyah, Cairo.

Al-Azraqī, Muhammad ibn 'Abd Allah, 2004, Tārīkh Makkah wa mā jā fihā min al-Athār, Maktabah al-Asadī, Saudi Arabia.

Al-Baydāwī, 'Abd Allah ibn 'Umar, 1997, Anwār al-Tanzīl wa Asrār al-Ta'wīl (vol. 3), Dār Ihyā al-Turāth al-'Arabī, Beirut.

Al-Birūnī, Abū al-Rayḥan, 1878 \& 2007, Al-Athār al-Bāqiyah 'an al-Qur'an al-Khāliyah, Leipzig.

Al-Bukhārī, Muḥammad ibn Ismāīil, 2002, Șahịḥ al-Bukhārī, Dār Ibn Kathīr, Damascus. Al-Dhahabī, Muhammad ibn Aḥmad, 2000, Mīzān al-ltidāl, Dār al-Ma'rifah, Beirut.

Al-Fākihī, Muḥammad ibn Isḥāq, 1994, Akhbār Makkah (vol. 1), Dār Khị̣r li al-Ṭibāáah, Beirut.

Al-Ḥamawī, Yāqūt, 1993, Mu'jam al-Buldān (vol. 3), Dār Șādir, Beirut.

Al-'Imādī, Abū al-Sa'ūd, 1936, Irshād al-'Aql al-Salīm lī Mazāyā al-Kitāb al-Karīm (vol. 3), Maktabah al-Riyāọ al-Ḥadìthah, Riyadh.

Al-Jāḥiz, 1965, al-Ḥayawān (vol. 7), Mușțafa Bābi al-Ḥalabī, Egypt.

Al-Kettānī, Alī, 2009, The Islamic existence in the Americas before Christopher Columbus, viewed 12 September 2016, from http://www.alikettani.info/news website_details.php?id=36

Al-Khatib al-Sharbīnī, Muḥammad ibn Aḥmad, 1881, Al-Sirāj al-Munīr (vol. 2), Mațba'at Bolāq, Egypt.

8.The reason why we have used fuil................................................... in many instance the initials and surnames may imply a different author who could have written a book with a similar title.

9.In some instances, the publishers are not indicated because some of the older publications merely state the place of publication. 
Al-Maghribī, Abū al-Hasan, 1982, Nashwat al-Tarab fi Tārīkh Jāhiliyat al-'Arab (vol. 1), Maktabat al-Aqsa, Amman.

Al-Maqrizī, 1985, al-Mawā'iz wa al-ltibār, Dār Șādir, Beirut.

Al-Nasafi, Abū al-Barakāt, 1989, Madārik al-Tanzīl wa Ḥaqa'iq al-Ta'wīl (vol. 2), Maktabat Nizār al-Bāz, Makkah.

Al-Naysāburī, Muslim ibn al-Ḥajjāj, 2006, Șaḥị̣ Muslim (vol. 1), Dār Ṭayibah, Madinah Al-Qāsimī, Muhammad Jamāl al-Dīn, 1957, Tafsīr al-Qāsimī, Dār Ihyā al-Kutub al-'Arabiyah, Beirut.

Al-Rāzī, Fakhr al-Dīn, 1981, Mafātīh al-Ghayb, Dār al-Fikr, Beirut.

Al-Shahrastānī, Muḥammad ibn 'Abd al-Karīm, 1992, al-Milal wa al-Nihal (vol. 2), Dār al-Kutub al-'Ilmiyyah, Beirut.

Al-Suhaylī, Abu al-Qāsim, 2000, Al-Rawḍ al-Anf (vol. 2), Dār lhyā al-Turāth al-'Arabī, Beirut.

Al-Suyūțī, Jalāl al-Dīn, 2003, al-Dur al-Manthūr fi Tafsīr al-Ma'thūr, Markaz Hijr II al-Buhūth, Saudi Arabia.

Al-Ṭabarī, Ibn Jarīr, 1986, Tārīkh al-Umam wa al-Mulūk, Bayt al-Afkār al-Dawliyah, Saudi Arabia.

Al-Ṭabarī, Ibn Jarīr, 1990, Tafsìr al-Ṭabarī (vol. 1), Mu’assat al-Risālah, Beirut.

Al-Ṭabbākh, Muḥammad Rāghib, (1923), Ilam al-Nubala., Matba'ah 'Ilmiyah, Aleppo.

Al-Ṭabbākh, Muḥammad Rāghib, 2003, Dhul Qarnayn wa Sadd al-Șin, Dār Gharrās, Kuwait.

Al-Tawhīīi, Abū Ḥayyān, 2004, al-Imtā' wa al-Muānasah (vol. 2), Maktabah al-'Asriyyah, Beirut.

Al-Tirmidhī, Abu 'Isā, 1996, Jāmi' al-Tirmidhī (vol. 5), Dār al-Gharb al-Islāmī, Beirut. Al-Zawzanī, 1983, Sharh al-Mu 'allaqāt al-'Ashr, Dār Maktabat al-Hayat, Beirut.

'Ali, Ismāīil, 1903, Al-Nukhbat al-Azhariyyah fi al-Kurat al-Ardiiyyah, Egypt.
Ālūsī, Muḥammad Shukrī, 2008, Rūḥ al-Ma'anī (vol. 16), Dār Ihyā al-Turāth al-'Arabī, Beirut.

'Azīm Abādi, Muhammad Shams al-Ḥaq, 1995, 'Awn al-Ma'būd Sharh Sunan Abī Dāwūd, Dār al-Fikr, Beirut.

Bewley, A., 1999, The Noble Qur'an, A new rendering of its meaning in English Bookwork, Norwich.

Diane, S.B., 2008, 'Toward an intellectual history of West Africa: The meaning of Timbuktu', in S. Jeppie \& B. Diagne (eds.), The meanings of Timbuktu, pp. 19-30, HSRC Press, Cape Town.

Ibn 'Abd al-Hakam, 1981, Futūh Mișr, Dār al-Kutub al-'Ilmiyah, Beirut.

Ibn 'Asākir, 'Alī ibn al-Hasan, 1995a, Tārīkh Dimasha (vol. 7), Dār al-Fikr, Beirut.

Ibn 'Asākir, 'Alī ibn al-Ḥasan, 1995b, Tārīkh Dimashq (vol. 17), Dār al-Fikr, Beirut.

Ibn Hazm, Ahmad, 1929, al-Fișal fi al-Milal wa al-Nihal (vol. 4), Maktabah al-Salām al-'Ālamī \& Maktabah Khānjī, Cairo.

Ibn Hishām, 'Abd al-Malik, 1990, Sīrah Ibn Hishām, Dār al-Kitāb al-'Arabī, Beirut.

Ibn Kathīr, 1999, Tafsìr al-Qur'an al-'Ażīm (vol. 5), Dār Țayyibah, Madinah.

Ibn Kathīr, Ismāīil ibn 'Umar, 2010, al-Bidāyah wa al-Nihāyah (vol. 1), Dār Ibn Kathīr, Damascus.

Ibn Munabbih, 1928, al-Tijān fi Mulūk Himyar, Markaz Dirāsāt wa al-Abhāth al-Yemeniyyah, Sanā'.

Ibn Nadīm, 1997, al-Fihrist, Dār al-Ma'rifah, Beirut.

Ibn Sīnā, 1952, al-Shifā, Ministry of Education, Egypt.

Kohn, G.C, 1999, Dictionary of wars, Routledge, London.

Makki, Shaykh Majd, 2015, Maqālāt al-'Allāmah Muhammad Rāghib al-Tabbākh, Arwiqa, Amman, Jordan.

Sukdaven, M., Mukhtar, A. \& Fernana, A.H., 2015, Qissat Dhul Qarnayn. Tale of the two horned one, Awqaf, Gauteng. 